\title{
Advances in the use of molecular tools in ecological and biodiversity assessment of aquatic ecosystems
}

Maria João Feio ${ }^{1, *}$, Ana Filipa Filipe ${ }^{2,3}$, Aina Garcia-Raventós ${ }^{2,3}$, Alba Ardura ${ }^{4}$, Ana Raquel Calapez $^{1,5}$, Ana Maria Pujante ${ }^{6}$, Andreia Mortágua7, Cesc Múrria ${ }^{8}$, Daniel Diaz-de-Quijano ${ }^{9}$, Filipa MS Martins ${ }^{2,10}$, Sofia Duarte ${ }^{11}$, Marta Sáinz Bariáin ${ }^{12}$, Rita Cordeiro ${ }^{13}$, Sinziana F. Rivera ${ }^{14}$, Leif O. S. Väisänen ${ }^{15}$, Amélia Fonseca ${ }^{13}$, Vítor Gonçalves ${ }^{13}$, Eva Garcia-Vazquez ${ }^{4}$, David Vieites Rodríguez ${ }^{16}$, Elena A. Ivanova ${ }^{9}$, Filipe O. Costa ${ }^{11}$, José Barquín ${ }^{12}$, Verónica Rojo $^{17}$, Joaquín Vierna ${ }^{17}$, Maria Fais ${ }^{11}$, Marcos Suarez ${ }^{4}$, Marko Nieminen ${ }^{18}$, Monica Hammers-Wirtz ${ }^{19}$, Olesia V. Kolmakova ${ }^{20}$, Maria Y. Trusova ${ }^{20}$, Pedro Beja ${ }^{2,3}$, Raquel González ${ }^{6}$, Serge Planes ${ }^{21}$ and Salomé FP Almeida ${ }^{7}$

${ }^{1}$ Marine and Environmental Sciences Centre - MARE \& University of Coimbra, Faculty of Sciences and Technology, Department of Life Sciences, Coimbra, Portugal.

2 CIBIO/InBio, Centro de Investigação em Biodiversidade e Recursos Genéticos, Universidade do Porto, Campus de Vairão, Vila do Conde, Portugal.

3 CIBIO/InBio, Centro de Investigação em Biodiversidade e Recursos Genéticos, Instituto Superior de Agronomia, Universidade de Lisboa, Lisboa, Portugal.

${ }^{4}$ Department of Functional Biology, University of Oviedo, C/ Julian Claveria s/n 33006-Oviedo, Spain.

${ }^{5}$ Linking Landscape, Environment, Agriculture and Food - LEAF, School of Agriculture, University of Lisbon, Lisbon, Portugal.

${ }^{6}$ Laboratorios Tecnológicos de Levante, S.L., Avda. Benjamin Franklin, 16, 46980 Paterna, Valencia, Spain.

7 Department of Biology and GeoBioTec - GeoBioSciences, GeoTechnologies and GeoEngineering Research Centre, University of Aveiro, Campus de Santiago, 3810-193, Aveiro, Portugal.

${ }^{8}$ Grup de Recerca Freshwater Ecology, Hydrology and Management (FEHM) and Institut de Recerca de la Biodiversitat (IRBio), Departament de Biologia Evolutiva, Ecologia i Ciències Ambientals, Facultat de Biologia, Universitat de Barcelona, Avinguda Diagonal 643, 08028 Barcelona, Catalonia, Spain.

${ }^{9}$ Siberian Federal University, Faculty of Biology and Biotechnology, Department of Aquatic and Terrestrial Ecosystems, Svobodnyy 79, 660041 Krasnoyarsk, Russian Federation.

10 Departamento de Biologia, Faculdade de Ciências da Universidade do Porto, Porto, Portugal.

11 Centre of Molecular and Environmental Biology (CBMA), Department of Biology, University of Minho, Campus de Gualtar, 4710-057 Braga, Portugal.

12 Environmental Hydraulics Institute, University of Cantabria, C/ Isabel Torres 15, Parque Científico y Tecnológico de Cantabria, 39011 Santander, Spain.

13 CIBIO, Centro de Investigação em Biodiversidade e Recursos Genéticos, InBIO Laboratório Associado, Pólo dos Açores, Portugal, Faculdade de Ciências e Tecnologia, Universidade dos Açores, 9501-801 Ponta Delgada, Portugal.

14 CARRTEL, INRA, Université de Savoie Mont Blanc, 75 Av. de Corzent, 74200 Thonon les bains Cedex, France.

15 Stream Ecology Research Group, Department of Ecology and Genetics, University of Oulu, Finland.

${ }^{16}$ National Museum of Natural Sciences, Spanish National Research Council (CSIC), Calle José Gutiérrez Abascal 2, 28006 Madrid, Spain.

17 Allgenetics, Edificio CICA, Campus de Elviña, s/n, E-15008 A Coruña, Spain.

18 FAUNATICA, Kutojantie 11, Espoo, Finland.

19 Research Institute for Ecosystem Analysis and Assessment, Kackertstr. 10, 52072 Aachen, Germany.

20 Biophysics Institute of the Siberian Branch of the Russian Academy of Sciences (BI SB RAN), 50, Akadem Gorodok, Str. 50, 660036 Krasnoyarsk, Russia. 
21 EPHE-UPVD-CNRS, Université de Perpignan, 52 Avenue Paul Alduy, 66860 Perpignan Cedex, France \& Laboratoire d'Excellence “Corail”, CRIOBE, BP 1013, 98729 Papetoai, Moorea, French Polynesia.

* Corresponding author: mjf@ci.uc.pt

Received: $28 / 11 / 18$

Accepted: 09/09/19

\begin{abstract}
Advances in the use of molecular tools in ecological and biodiversity assessment of aquatic ecosystems

Conservation and sustainable management of aquatic ecosystems is a priority in environmental programs worldwide. However, these aims are highly dependent on the efficiency, accuracy and cost of existent methods for the detection of keystone species and monitoring of biological communities. Rapid advances in eDNA, barcoding and metabarcoding promoted by high-throughput sequencing technologies are generating millions of sequences in a fast way, with a promising cost reduction, and overcoming some difficulties of the traditional taxonomic approaches. This paper provides an updated broad perspective of the current developments in this dynamic field presented in the special session (SS) "The use of molecular tools in ecological and biodiversity assessment of aquatic ecosystems" of the XIX Congress of the Iberian Association of Limnology (AIL2018), held in Coimbra, Portugal.

Developments presented are mainly focused on the Iberian Peninsula (Portugal and Spain, including Atlantic Macaronesian islands) but include studies in France, Germany, Finland, Russia (Siberia) and South America. The networks within which these researchers are involved are yet even broader, profiting from existing molecular facilities, and traditional taxonomic expertise, which can be viewed as a characteristic of this new research area. It was evident in the SS that the use of molecular tools is widespread, being used to study a diversity of aquatic systems, from rivers' headwaters to estuaries and coastal lagoons, and volcanic, mountain and frozen lakes to hot springs. The organisms targeted are likewise varied and include fish, macroinvertebrates, meiofauna, microalgae such as diatoms and dinoflagellates, other protists, fungi, and bacteria (cyanobacteria and other). Some studies address the whole biodiversity (i.e., all species present independently of the taxonomic group) from environmental samples of water, biofilms and preservative solution from field samples (e.g., ethanol from macroinvertebrate samples). Great advances were acknowledged in the special session, namely in the use of metabarcoding for detecting hidden biodiversity, juvenile stages, low-abundance species, non-indigenous species and toxicity potential, and ultimately for ecological monitoring of diatoms and invertebrates. Yet, several drawbacks were highlighted and need further work, which include: taxonomic gaps in the reference databases (including gaps at species level and on intraspecific variability) or absence of public databases (e.g. for meiofauna), still high sequencing costs, the need of a substantial bioinformatics effort, difficulties in establishing the amount of environmental sample necessary for a good DNA extraction and the need for testing different genetic markers to obtain accurate results.
\end{abstract}

Key words: eDNA, metabarcoding, conservation, ecological quality, species detection, rivers, lakes, thermal springs, estuaries, lagoons

\title{
RESUMO
}

\section{Avanços no uso de ferramentas moleculares na avaliação ecológica e biodiversidade dos ecossistemas aquáticos}

A conservação e gestão sustentável dos ecossistemas aquáticos é uma prioridade nos programas ambientais em todo o mundo. No entanto, esses objetivos são altamente dependentes da eficiência, precisão e custo dos métodos existentes para detectar espécies e monitorizar comunidades biológicas. Avanços recentes no que respeita ao ADN ambiental e 'barcoding' e 'metabarcoding', promovidos por tecnologias de sequenciação designadas 'high-throughput sequencing', têm gerado milhões de sequências de forma rápida, com uma promissora redução de custos num futuro próximo, e superando algumas dificuldades das abordagens taxonómicas tradicionais. Este artigo vem fornecer uma perspetiva atualizada e abrangente dos desenvolvimentos neste campo que foram apresentados na sessão especial (SE) "O uso de ferramentas moleculares na avaliação ecológica e da biodiversidade dos ecossistemas aquáticos", no XIX Congresso da Associação Ibérica de Limnologia (AIL2018) realizado em Coimbra, Portugal.

Os desenvolvimentos apresentados centram-se principalmente na Peninsula Ibérica (Portugal e Espanha, incluindo as ilhas atlânticas), mas também em França, Alemanha, Finlândia e Rússia (Sibéria). No entanto, as redes em que estes investigadores estão envolvidos são ainda mais amplas, aproveitando as infraestruturas moleculares e o conhecimento taxonómico existentes. Ficou claro na SE que o uso de ferramentas moleculares está disseminado, sendo usado numa diversidade de sistemas aquáticos, desde as cabeceiras dos rios aos estuários e lagoas costeiras, e desde lagos vulcânicos, de montanha e congelados, a fontes 
termais. Os organismos estudados são também variados e incluem peixes, macroinvertebrados, meiofauna, microalgas tal como diatomáceas e dinoflagelados, outros protistas, fungos e bactérias (cianobactérias e outros). Alguns estudos abordam toda a biodiversidade a partir de amostras ambientais de água, biofilmes e solução conservante. Grandes avanços foram reconhecidos na sessão especial, nomeadamente no uso de 'metabarcoding' para a deteção de biodiversidade críptica, estádios juvenis, espécies de reduzida abundância, espécies não nativas, do potencial de toxicidade e, finalmente, para a monitorização ecológica de diatomáceas e invertebrados. No entanto, dificuldades também foram assinaladas, que necessitarão de mais investimento futuro, e que incluem: lacunas taxonómicas das bibliotecas de referência (incluindo ao nível da espécie e da intra-variabilidade de espécies), ausência de bibliotecas públicas (por exemplo, para meiofauna), altos custos de sequenciação, a necessidade de um esforço substancial de bioinformática, dificuldades em estabelecer a quantidade de amostra ambiental necessária para uma boa extração de DNA e a necessidade de testar diferentes marcadores genéticos para obter resultados precisos.

Palavras chave: eDNA, metabarcoding, conservação, qualidade ecológica, detecção de espécies, rios, lagos, fontes termais, estuários, lagoas

\section{INTRODUCTION}

Biological diversity means the variability among living organisms from all sources including terrestrial, marine and other aquatic ecosystems and ecological complexes of which they are part; this includes diversity within species, between species and of ecosystems (Wilcox, 1984). Biodiversity reflects the ecosystem's health and resilience to withstand and recover from a variety of disturbances. Therefore, it is essential to discover and understand the biodiversity present in a certain study area, which is a challenging task. Most of the traditional approaches for assessing biodiversity, where species are identified based on their morphological characters, are time-consuming, expensive and require high taxonomic expertise (Leese et al., 2016). On the other hand, rapid assessment based on an estimation of the abundance and distribution of target species through

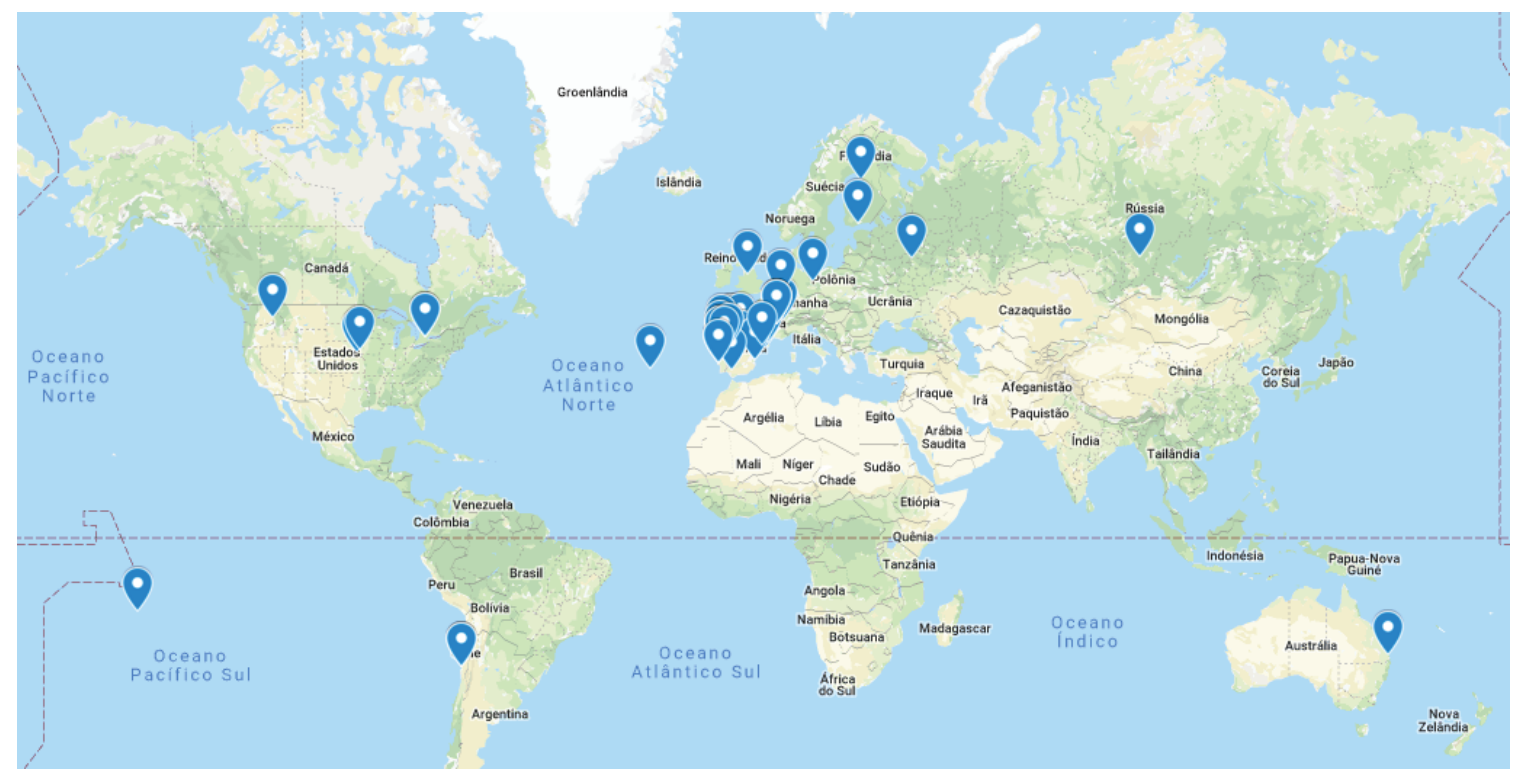

Figure 1. Distribution of the contributors to the special session "The use of molecular tools in ecological and biodiversity assessment of aquatic ecosystems" of the XIX Congress of the Iberian Association of Limnology (AIL2018) in the World. Image produced in Google Maps (2019). Distribuição dos autores da sessão especial "O uso das ferramentas moleculares na avaliação ecológica e biodiversidade dos ecossistemas aquáticos”, do XIX Congresso da Associação Ibérica de Limnologia (AIL2018) no mundo. Imagem produzida no Google Maps (2019). 
molecular tools may be conducted in a short time more cheaply and easily (Minchin et al., 2016). For instance, using species-specific DNA markers, the presence of one target species from water samples can be detected using PCR and simple electrophoresis in agarose gel. This is an efficient and convenient approach when the target species is known because it is a reproducible, fast and a cost-efficient method (Ardura et al., 2015a; Clusa et al., 2016; Devloo-Delva et al., 2016; Ardura et al., AIL2018).

The special session "The use of molecular tools in ecological and biodiversity assessment of aquatic ecosystems" of AIL2018 (XIX Iberian Association of Limnology meeting in Coimbra, Portugal, June 2018) aimed to present and discuss recent studies undertaken in the Iberian Peninsula, other European countries and South America, in order to promote knowledge exchange and envisage on future research directions in this area. The authors represented 13 countries and 46 institutions (including research institutions, official agencies and companies), which highlights the fast development of this area around the world and the importance of broad networks in the advancement of this particular research field (Fig. 1).

The different ways of using molecular approaches in the context of ecological and biodiversity assessment in aquatic ecosystems highlighted in the studies presented in the SS (Table 1) were synthesized in the section "Perspectives on the use of molecular tools." From those studies, we extracted the main contributions for the area (section "Main findings"), as well as the main problems and gaps identified by the researchers (section "Main drawbacks") and ended with general inferences and future research directions (section "Conclusions").

\section{PERSPECTIVES ON THE USE OF MOLE- CULAR TOOLS}

\section{Improvement of biodiversity detection and biological quality monitoring with molecular tools}

\section{Biodiversity}

Molecular tools are particularly useful to assess the diversity of concealed communities, allowing a more accurate species detection and distribution in a specific ecosystem. This is the case of the meiofauna, which comprises organisms between 30-1000 $\mu \mathrm{m}$ (Higgins \& Thiel, 1988). Due to their small size, morphotaxonomic inventories can largely fail to identify accurately (Alves et al., 2015). Various taxonomic meiofaunal groups of an estuary in the North of Portugal have been detected by a target region (Fais et al., AIL2018). Phytoplankton and general microeukaryotic plankton dynamics under the formation of ice-and-snow cover were studied in a Siberian mountain lake through molecular techniques (Díaz-Quijano et al., AIL2018).

Other examples of detection of small organisms are the microalgae dinoflagellates or diatoms, which have additionally high morphological similarities and lack of unique characteristics between different species (Lin et al., 2009). The eDNA (environmental DNA) analysis has been used in French coastal lagoons to detect a set of signal species using mitochondrial cytochrome oxidase I gene (COI), such as, 21 genera of Dinoflagellates and 9 genera of diatoms, including Chaetoceros and Nitzschia involved in harmful algal blooms (HABs); and invasive invertebrate species (barnacles, copepods, polychaeta and ascidians), some of them being pollution indicators (Polydora cornuta, Ficopomatus enigmaticus and Hydroides elegans) (Ardura et al., AIL2018).

Ecological impact of algal toxicity is also being investigated through molecular tools (Cordeiro et al., AIL2018). Toxins are transferred along the food chain, from different microalgae (mainly Dinoflagellates, Cyanobacteria, and Diatoms) and HABs can be responsible for massive fish mortality (Thangaraja et al., 2007), while the presence of toxins in fish or shellfish can cause severe human diseases (e.g., diarrheic shellfish poisoning). In the Azorean archipelago (Portugal), the potential for cyanotoxin production was assessed in thermal environments and freshwater lakes, which are common in these volcanic islands. The confirmation of cyanobacteria's DNA and potential risk of cyanotoxin production in the eDNA samples (Cordeiro et al., AIL2018), revealed to be an efficient method for monitoring these ecosystems and help to prevent threats to public and environmental health (Pear- 
son \& Neilan, 2008; Salmaso et al., 2017).

Genetic tools have been increasingly used for studying invasions, because it allows species identification (e.g. Ardura et al., 2010; Ardura \& Planes, 2017), determination of the region of origin (Ardura et al., 2013) and time of initial incursion of non-indigenous species (Hilbish et al., 2000; Rius et al., 2014; Teske et al., 2014). This is especially important as the number of introduced species has been increasing during the last decades, in freshwater ecosystems (Elvira \& Almodóvar, 2001; Anastácio et al., 2018). One example is the minnow species (Phoxinus genus), a freshwater fish that has been used as live bait since the 1900s. Individuals were sampled in the Douro basin (Portugal) and morphologically identified as Phoxinus bigerri, a common minnow in the Iberian Peninsula. Nevertheless, barcoding showed that the population caught closer to the Atlantic Ocean is phylogenetically closer to Phoxinus phoxinus from Charente river in France, confirming for the first time the presence of this species in the Douro basin (Garcia-Raventós et al., AIL2018).

Apart from the tools used for single and mixed-organism samples, other sources of DNA have been explored for faster biodiversity assessment such as, DNA from sediment samples, water or sample preservation liquids (e.g., Aylagas et al., 2016; Deiner et al., 2017; Hajibabaei et $a l ., 2012)$. These approaches avoid the traditional sampling protocols that require a large investment in human resources with many specialists studying different biological elements. In these cases, DNA is extracted directly from environmental samples (e.g., water) followed by high-throughput sequencing (HTS) metabarcoding. Taking into account previous results of DNA extraction directly from the water (Ardura et al., 2015a; Zaiko et al., 2015; Ardura \& Planes, 2017) a HTS tool was developed to obtain a baseline of biodiversity from 10 different coastal lagoons (Ardura et al., AIL2018).

Alternatively, Martins and collaborators (CIBIO/InBIO University of Porto, Aqualogus company and Polytechnic Institute of Bragança) are exploring the option of DNA metabarcoding from preservative ethanol of freshwater macroinvertebrate samples (Martins et al., AIL2018; Martins et al., 2019). This approach requires following the Water Framework Directive (WFD; European Union 2000) sampling protocols but avoids the sorting step of separating animals in a sample from vegetation, sediment and litter, which is very time-consuming. The authors are examining the performance of different laboratory procedures on species detection based on the preservative liquid, and compared taxa recovery with the conventional morphological method. More than half of the taxa found in ethanol were macroinvertebrates targeted by WFD, while the remaining percentage was identified as, e.g., bacteria, Stramenopiles, terrestrial invertebrates, amphibians and fishes (Martins et al., AIL2018; Martins et al., 2019).

\section{Biological quality monitoring}

The use of molecular tools in biological quality monitoring is becoming more and more realistic and several studies highlighted its potential (e.g., Filipe et al., 2018; Filipe et al., AIL2018). Comparison between morphology and metabarcoding-based approaches to determine species composition at estuarine sites indicated that species richness, one of the metrics frequently used in bioassessment, would be considerably underestimated if only morphological methods were used (Lobo et al., 2017a).

In the ecological quality assessment of rivers, diatoms are one of the obligatory elements, according to the WFD. Thus, a considerable effort has been made to develop diatom metabarcoding and optimize different stages of the process (choice of primers, Kermarrec et al., 2014; diatom barcode database, Rimet et al., 2016; DNA extraction, Vasselon et al., 2017a; quantification bias, Vasselon et al., 2018; bioinformatics treatment, Coissac et al., 2012). In France, diatom metabarcoding has been applied successfully at small (80 samples, Vasselon et al., 2017b; Rivera et al., 2020) and larger monitoring networks (447 samples). In rivers of Central Portugal, the comparison between the Portuguese official monitoring index for diatoms (IPS Indice de Polluosensibilité Spécifique), calculated based on morphological identification data and on Operational Taxonomic Units (OTUs) converted into species data, showed a high correlation 
Table 1. Biological groups, water bodies and barcode genes assessed in studies presented in the special session "The use of molecular tools in ecological and biodiversity assessment of aquatic ecosystems" of the XIX Congress of the Iberian Association of Limnology (AIL2018). Grupos biológicos, massas de água e barcodes analisados nos estudos apresentados na sessão especial "O uso das ferramentas moleculares na avaliação ecológica e biodiversidade dos ecossistemas aquáticos", do XIX Congresso da Associação Ibérica de Limnologia (AIL2018).

\begin{tabular}{|c|c|c|c|}
\hline Biological group & $\begin{array}{l}\text { Type of water } \\
\text { body/location }\end{array}$ & Barcode gene & Reference \\
\hline $\begin{array}{l}\text { Total biodiversity - eDNA } \\
\text { (water) }\end{array}$ & $\begin{array}{l}\text { Coastal lagoons of } \\
\text { Gulf of Lyon - } \\
\text { France }\end{array}$ & COI, $18 \mathrm{~S}$ & $\begin{array}{l}\text { Ardura et al., } \\
\text { AIL2018 }\end{array}$ \\
\hline $\begin{array}{l}\text { Total biodiversity - eDNA } \\
\text { (water, sediment) }\end{array}$ & $\begin{array}{l}\text { Rivers and estuaries } \\
\text { - Pas, Asón, Miera } \\
\text { rivers (Cantabria), } \\
\text { Douro, Ebro }\end{array}$ & $\begin{array}{l}\text { COI, } 18 \mathrm{~S}, \\
16 \mathrm{~S}\end{array}$ & $\begin{array}{l}\text { Sainz-Bariáin et } \\
\text { al., AIL2018 }\end{array}$ \\
\hline Fish & $\begin{array}{l}\text { Rivers - Douro } \\
\text { catchment }\end{array}$ & $\begin{array}{l}12 \mathrm{~S}-\mathrm{MiFish} \\
\text { region }\end{array}$ & $\begin{array}{l}\text { Filipe et al., } \\
\text { AIL2018 }\end{array}$ \\
\hline $\begin{array}{l}\text { Fish (non-indigenenous species) } \\
\text {-Phoxinus phoxinus }\end{array}$ & $\begin{array}{l}\text { Rivers - Douro } \\
\text { catchment }\end{array}$ & COI, Cytb & $\begin{array}{l}\text { Garcia-Raventós } \\
\text { et al., AIL2018 }\end{array}$ \\
\hline $\begin{array}{l}\text { Macroinvertebrates and eDNA } \\
\text { (ethanol) }\end{array}$ & $\begin{array}{l}\text { Rivers - Tua (Douro } \\
\text { catchment) }\end{array}$ & $\mathrm{COI}$ & $\begin{array}{l}\text { Martins et al., } \\
\text { AIL2018 }\end{array}$ \\
\hline Macroinvertebrates & $\begin{array}{l}\text { Rivers - Spain } \\
\text { (Mediterranean } \\
\text { rivers), Finland and } \\
\text { Germany }\end{array}$ & $16 \mathrm{~S}$ & $\begin{array}{l}\text { Pujante } \text { et al., } \\
\text { AIL2018 }\end{array}$ \\
\hline $\begin{array}{l}\text { Macroinvertebrates and eDNA } \\
\text { (water) }\end{array}$ & $\begin{array}{l}\text { Rivers - Lobregat, } \\
\text { (Mediterranean river, } \\
\text { Catalonia) }\end{array}$ & $\mathrm{COI}$ & $\begin{array}{l}\text { Múrria et al., } \\
\text { AIL2018 }\end{array}$ \\
\hline Diatoms & $\begin{array}{l}\text { Rivers - central } \\
\text { Portugal }\end{array}$ & $r b c L$ & $\begin{array}{l}\text { Mortágua et al., } \\
\text { AIL2018; } \\
\text { Mortágua et al., } \\
2019 \\
\end{array}$ \\
\hline Diatoms & $\begin{array}{l}\text { Lakes - Bourget, } \\
\text { France }\end{array}$ & $r c b L$ & $\begin{array}{l}\text { Rivera } \text { et al., } \\
\text { 2018; Rivera } \text { et } \\
\text { al. AIL2018 } \\
\end{array}$ \\
\hline $\begin{array}{l}\text { Biofilms (bacteria, fungi, } \\
\text { microalgae) }\end{array}$ & Rivers (mesocosms) & $16 \mathrm{~S}, 18 \mathrm{~S}$ & $\begin{array}{l}\text { Calapez et al., } \\
\text { AIL2018; Calapez } \\
\text { et al., } 2019 \\
\end{array}$ \\
\hline Phytoplankton & $\begin{array}{l}\text { Mountain lake - } \\
\text { Oiskoe, Siberia }\end{array}$ & $18 \mathrm{~S}$ & $\begin{array}{l}\text { Díaz-Quijano et } \\
\text { al., AIL2018 }\end{array}$ \\
\hline Algae (toxicity, Cyanobacteria) & $\begin{array}{l}\text { Thermal waters and } \\
\text { freshwater lakes - } \\
\text { Azores islands }\end{array}$ & $\begin{array}{l}16 \mathrm{~S} \text { and sxtA, } \\
\text { sxtI, sxtH, } \\
\text { sxtG for } \\
\text { saxitoxinas, } \\
\text { anaC, anaF } \\
\text { for anatoxina, } \\
\text { and mcyC, } \\
\text { mcyD, mcyE, } \\
\text { mcyG for } \\
\text { microcistina }\end{array}$ & $\begin{array}{l}\text { Cordeiro et al., } \\
\text { AIL2018 }\end{array}$ \\
\hline Meiofauna (sediment) & $\begin{array}{l}\text { Estuary - Lima river, } \\
\text { Portugal }\end{array}$ & COI, 18S & $\begin{array}{l}\text { Fais et al., } \\
\text { AIL2018 }\end{array}$ \\
\hline
\end{tabular}


(Mortágua et al., AIL2018). Besides, more than half (ca. $56 \%$ ) of the samples shared the same water quality class either using the conventional or the molecular approach. These results show the potential for adaptation of present taxonomic indices to molecular data, as it was concluded in studies in Mayotte island, France (Vasselon et al., 2017b) and in the UK (Kelly et al., 2018).

The benthic invertebrates are another compulsory quality element of the WFD. In Portugal, five sites sampled in Tua river (Douro basin) were classified to the same quality status through both morphological identification and ethanol-based DNA metabarcoding (Martins et al., AIL2018; Martins et al., 2019) when applying the Iberian Biological Monitoring Working Party (IBMWP) index with presence/absence data, at family level (Alba-Tercedor et al., 2002). However, only about half of the species identified by metabarcoding were detected by morphology, whereas the former missed about $20 \%$ of the species identified morphologically, corresponding to taxa with a low frequency $(<5$ individuals).

In Valencia, the Laboratorios Tecnológicos de Levante (Pujante et al., AIL2018) in the context of the European project BIOWAT-KIT (DNA-based kit for biodiversity assessments and biomonitoring of European water bodies), are developing and validating a genomic tool for the identification and assessment of diversity of benthic invertebrate communities in Europe, with the aim of improving and facilitating the bioassessment. An audit (made by taxonomists) to an official European freshwater monitoring program, based on macroinvertebrate samples, revealed that $29-30 \%$ of the specimens had been overlooked by the primary taxonomists (Haase et al., 2010). For $16 \%$ of the samples, these discrepancies led to different final ecological assessment and demonstrated the need for adequate quality control and auditing in freshwater monitoring. Múrria and collaborators (University of Barcelona, Spain and Salford, Manchester, UK) used metabarcoding techniques to compare the estimates of the ecological status using traditional morpho-taxonomy against high-throughput DNA sequencing of: 1) bulk sampling (after sorting individuals from multi-habitat Surber samples), 2) eDNA (water samples) and 3) invertebrate drift sampling (intervals of 1 hour). Results showed that while the traditional and bulk sampling approaches detected essentially riverine species, the eDNA also captured terrestrial associated fauna (Múrria et al., AIL2018).

Development of indices based on molecular information for the monitoring of aquatic ecosystems (i.e., ecological status or conservation status) is the purpose of the work developed at the University of Cantabria. Yet here, the main goal is a global assessment of water bodies through eDNA from water and sediment (Sainz-Bariáin et al., AIL2018). Additionally, the study of bacterial diversity and primary producers through metagenomics is aimed, which could give complementary information on ecosystem functions (e.g., organic matter degradation or primary production under different conditions).

Molecular analysis constitutes, in addition, a simpler way of analysing the impact of anthropogenic and natural alterations in complex communities composed of microorganisms. A study in mesocosms run by Calapez and collaborators (Universities of Aveiro and Coimbra, Portugal) analysed stream biofilm responses to multiple-stressors typical of Mediterranean streams and found biofilm community shifts induced by flow stagnation, organic loads and grazing activity. Specifically, the OTUs determination helped to investigate how biofilm microbial communities' proportions changed under the different stressor combinations more quickly. The interaction of those three stressors altered algae, fungi and bacteria diversity proportions within the biofilm, with a synergistic effect on fungal diversity, while algae and bacteria had an antagonistic response to stressors' interaction (Calapez et al., AIL2018).

\section{Molecular analysis in aquatic water bodies}

Different aquatic systems have been studied through molecular techniques by the teams present in the SS: rivers and streams, lakes, thermal waters and estuaries and coastal lagoons.

\section{Rivers and streams}

Rivers of NW Iberian Peninsula (Portugal and Spain) have been studied under the FRESHING 
project (Next-generation biomonitoring: freshwater bioassessment and species conservation improved with metagenomics) by $\mathrm{CIBIO} / \mathrm{InBIO}$, covering up to 150 sampling sites (Filipe et al., AIL2018). Each site was sampled using conventional methods along with water sampling from different microhabitats in order to maximize the detection of several taxa present in the water body through eDNA. However, results shown in the special session focused on freshwater fish. In central Portugal, the studies of the University of Coimbra and Aveiro and partners from INRA Thonon, France, include 88 sites located in the catchments of rivers Vouga, Mondego and Lis in a total area of $11215 \mathrm{~km}^{2}$. These sites were sampled for algae and macroinvertebrates, but present results report to diatoms only (Mortágua et al., AIL2018; Mortágua et al., 2019).

In the BIOWAT-KIT project, three rivers from each country (Spain, Finland and Germany) have been selected to test a genomic tool across different European regions covering a variety of climatic and geomorphological conditions. In Spain, the rivers are typically Mediterranean with different characteristics: Júcar is a calcareous mountain river; Mijares is a low-mountain river with high mineralization; while the Turia river is a low altitude river (Pujante et al., AIL2018). Another Mediterranean river from Catalonia, the Llobregat (156 km in length), was studied by Múrria and collaborators, which covers a gradient of pollution and anthropogenic impact. This is a well-studied river (Munné \& Prat, 2004, 2011), which includes a pollution gradient from pristine headwater reach, through site located downstream of a big reservoir or salt mining, to urban and agricultural landscapes at lowlands. A sampling of macroinvertebrates was done in 5 sites along the river (Múrria et al., AIL2018).

In Cantabria, two rivers, Pas and Asón (Spain), with temperate hyper-oceanic climate with sub-Mediterranean characteristics were studied with molecular tools to compare diversity under pristine and polluted conditions. In addition, water and biofilm samples were recently collected from 96 river sites belonging to the Douro, Ebro and Cantabrian basins (Spain). These sites were sampled to determine the total biodiversity from microorganisms to vertebrates and are currently being identified (Sainz-Bariáin et al., AIL2018).

\section{Lakes}

The studies presented in the SS addressed a wide diversity of freshwater lakes. The Azores archipelago (Portugal) located in the North Atlantic Ocean is composed of nine islands, which are very important and unique in terms of biodiversity, climate, volcanic activity and geomorphology (Antunes \& Rodrigues, 2011). Fifteen freshwater lakes from the Archipelago of the Azores in São Miguel, Pico, Flores and Corvo islands were studied to investigate cyanotoxin production potential.

In France, diatom metabarcoding has been applied to assess the structure of diatom community and the ecological status of the littoral zone of Lake Bourget (deepest French lake). The structure of the assemblages based on the morphological (taxa lists) and molecular (OTUs lists) identification of diatoms were well correlated. However, the ecological status of the lake varied between these two methods since floristic inventories differed significantly (Rivera et al., 2018; Rivera et al., AIL2018). The main reason for this discrepancy was the incompleteness of the diatom reference database (Diat.barcode, formerly called R-Syst::diatom in Rimet et al., 2016).

In Cantabria, five mountain lakes were sampled for molecular analysis of environmental samples (water and sediment). The first is located at ca. $1870 \mathrm{~m}$ of altitude in the Liordes Valley, a unique ecosystem in the Picos de Europa massif, located in a glacial-karst depression surrounded by calcareous walls. The Lloroza lakes (ca. 1800 $\mathrm{m}$ of altitude) are small lagoons of karstic nature located in Picos de Europa National Park in the Cantabria province. Finally, the Enol and Ercina (at ca. $110 \mathrm{~m}$ of altitude) are two glacial lakes forming the Covadonga lakes located within the Picos de Europa National Park in the Asturias province. These samples are still being processed (Sainz-Bariáin et al., AIL2018).

In Siberia, the Oiskoe mountain lake is being studied with phytoplankton samples through metabarcoding from a conservation perspective (Diaz-de-Quijano et al., AIL2018). Located in the Ergaki Natural Park, West Sayan Mountains, is a 
poorly studied area due to its extreme climate with a wide range of annual temperatures $\left(-41^{\circ} \mathrm{C}\right.$ to $+32^{\circ} \mathrm{C}$ ). The lake is surrounded by a mosaic landscape of bogs, sparse taiga forest, scree and alpine tundra and biodiversity has particular adaptations to these conditions (Anishchenko et al., 2015). However, human activities, namely tourism and global warming in South Siberia and Central Asia, are the present threats to these ecosystems.

\section{Thermal waters}

In São Miguel island, in the Azorean archipelago, environmental samples were collected from 21 thermal sites, including hot springs, thermal pools and ponds, thermal streams and hydrothermal vents, with temperatures ranging from $28{ }^{\circ} \mathrm{C}$ to over $90^{\circ} \mathrm{C}$ (Cordeiro et al., AIL2018). Cyanobacteria were isolated from these samples and deposited in BACA-Banco de Algas e Cianobactérias dos Açores (Universidade dos Açores), which is part of REBECA (Red de excelencia en biotecnología azul (algas) de la región de la Macaronesia). From the 40 strains isolated, 24 strains and environmental samples were targeted for cyanotoxin production potential through conventional PCR. Preliminary results show that none of the studied cyanobacteria strains have cyanotoxin production potential (Cordeiro et al., AIL2018).

\section{Estuaries and coastal lagoons}

Finally, studies have been undertaken in estuaries and coastal lagoons. A proof-of-concept study (Lobo et al., 2017b) on the application of DNA metabarcoding for monitoring estuarine macrozoobenthic communities has been conducted in the Sado estuary (SW Portugal). The metabarcoding approach was able to discriminate macrozoobenthic communities among sampling sites successfully and provided biotic index levels comparable to the morphology-based approach (Lobo et al., 2017b). Up north, in river Lima (NW Portugal), the estuarine area has become an important Portuguese harbour, used for commercial navigation and fishing activities and is subjected to constant dredging as well as the input of agricultural run-off and urban and industrial sewage (Sousa et al., 2007). The University of
Minho (Portugal) team is monitoring meiofauna communities of this estuary through metabarcoding, annually, whose preliminary results were presented at the AIL conference (Fais et al., 2018, AIL2018).

In Cantabria, five sediment and five water samples were taken from 3 estuaries (Pas, Miera, and Asón) characterized by large intertidal surfaces and dominated by the tidal dynamic, making them well-mixed estuaries. This coast is subjected to various anthropogenic pressures. These sites have been sampled to determine general biodiversity through molecular analysis.

The team from the University of Oviedo (Spain) has been using metabarcoding (eDNA) to determine the biodiversity and detect particular organisms in the coastal lagoons of Gulf of Lyon, in the French Mediterranean coast (Ardura et al., AIL2018). Ten lagoons were analysed: Berre, Beaduc, Bages-Sigean, La Palme, Leucate, Mejean, Prevost, Thau, Vic and Canet. These ecosystems provide habitat for many species, nursery areas and feeding grounds for marine and estuarine fish (Perez-Ruzafa et al., 2011). They support important fisheries and allow for intensive aquaculture exploitation (Cataudella et al., 2015). Despite most of them being under protection, they still suffer from several threats derived from human activities such as pollution, eutrophication, climate change and introduction of non-native species $(\approx 100$ non-indigenous species were identified; Reizipoulou et al., 1996; Chapman, 2012).

\section{Selection of adequate barcode genes for each group of organisms}

The selection of barcode genes varies with the target taxonomic group studied and the focus of the studies. The researchers took different options in the studies presented in the SS:

\section{COI}

The DNA barcode region elected most frequently for the identification of individualized specimens is a fragment of the mitochondrial COI gene (Herbert et al., 2003). The Cytochrome c (COI) is an amino acid sequence that is highly conserved 
in eukaryotes, differing by only a few residues. There are robust universal primers for it that recover most animal phyla, and thousands of reference sequences are available in public databases such as BOLD and GenBank (Ratnasingham \& Hebert, 2013; Hebert et al., 2013). However, the high variability in the third position of the COI codons makes it difficult to design universal primers for metabarcoding DNA studies (Ficetola et al., 2010). For fish identification, most used barcode markers in DNA reference collections are the COI and cytochrome $b$ (Cytb) genes, other mitochondrial genes, which can confirm taxonomic identification at the species level. However, some studies are showing that COI might not be the best option for assessing and monitoring freshwater fish diversity using environmental DNA from water because this marker might not contain suitably conserved regions (e.g., Deagle et al., 2014). Instead, the potential of using the MiFish region from the ribosomal $12 \mathrm{~S}$ is under consideration (Miya et al., 2015; Filipe et al., AIL2018).

For Iberian freshwater macroinvertebrates, public repositories for COI DNA barcodes cover $35 \%$ of the taxa (3348 morphospecies) (Múrria et al., AIL2018, Múrria et al., 2020). However, this coverage is highly variable across taxonomic groups. For instance, Odonata (79 species, 54.43 $\%$ ), Hemiptera (81 species, $54.32 \%$ ), Mollusca (65 species, $53.85 \%$ ), Trichoptera (390 species, $50.77 \%$ ) and Crustacea (10 species, $50.5 \%)$ were the best-represented groups, whereas Diptera (1693 species, $23.21 \%$ ), and Plecoptera (135 species, $31.11 \%$ ) were the less barcoded orders. Portuguese invertebrate communities sampled were also processed for metabarcoding using a small COI fragment (313bp) by Martins and collaborators in CIBIO (AIL2018; Martins et al., 2019). The HTS data were identified against the invertebrate collection of the InBIO Barcoding Initiative (at CIBIO-UP) that includes hundreds of specimens of macroinvertebrate taxa from northeast Portugal.

Macroinvertebrates and marine fish have been the target of comprehensive DNA barcoding campaigns across multiple coastal ecosystems in continental Portugal. The primary marker was the COI, occasionally supplemented by other mark- ers (e.g., Borges et al., 2012). In the Lima estuary, DNA from meiofauna communities was extracted from intertidal sediments. In this case, the target genes were the $\mathrm{COI}$ and $18 \mathrm{~S}$ ribosomal RNA (18S rDNA) gene. MiSeq amplicon sequences were processed in mothur (version 1.39.5, Schloss et al., 2009) by using appropriate bioinformatic procedures; while the taxonomy of the processed sequences were assessed by blasting against the full ntNCBI database (Fais et al., AIL2018). This database was chosen due to the lack of adequate reference sequences in better-known databases, such as BOLD (Ratnasingham \& Hebert, 2007) and Silva (Pruesse et al., 2007). In the French coastal lagoons, the invertebrate communities were as well analysed from eDNA with COI marker.

\section{$18 S, r b c L$ and $16 S$}

In the project BIOWAT-KIT a preliminary evaluation of different genomic regions using publicly available sequence data was carried out in order to identify the best-suited DNA barcode marker for the identification of 141 families of invertebrates belonging to four different phyla (Platyhelminthes, Annelida, Mollusca, and Arthropoda). Several primer pairs have been designed, including a degenerate primer pair and a cocktail of group-specific primers, which will presumably amplify all the target invertebrate taxa present in freshwater samples. Based on the results, the mitochondrial 16S gene was selected for the DNA metabarcoding analysis of freshwater invertebrate communities within this project, since it combines both conserved regions suitable for primer design, and variable regions with good taxonomic resolution at the family level (and potentially, also at the genus or species level) (Pujante et al., AIL2018).

In Thonon (France), the INRA team targeted several genes for diatoms (18S, COI, $r b c L$ ) (Kermarrec et al., 2013). While COI is found in mitochondrial DNA of eukaryotic organisms, the $18 \mathrm{~S}$ is part of the ribosomal RNA of eukaryotes and the ribulose-1,5-bisphosphate carboxylase/oxygenase $(r c b L)$ is present in plants chloroplasts. The $r c b L$ showed to be the most suitable barcode for biomonitoring purposes with diatoms (Ker- 
marrec et al., 2013; Kermarrec et al., 2014; Pawlowski et al., 2016). Thus, DNA metabarcoding of periphytic diatom community samples from Portuguese and French rivers included a step for DNA extraction using commercial kit NucleoSpin ${ }^{\circledR}$ Soil and a second step for DNA sequencing with MiSeq system (Illumina) using $r b c L$ plastid gene (312 bp barcode) (Mortágua et al., AIL2018, Mortágua et al., 2019, Rivera et al., 2018; Rivera et al., 2020). Sample sequences obtained from metabarcoding were then analysed using the software mothur (version 1.39.5, Schloss et al., 2009). Taxonomic assignment of OTUs was based on the Diat.barcode library (available at: https://www6.inra.fr/carrtelcollection_eng/Barcoding-database). In French lagoons, the process was similar, but the DNA extraction was done with the kit Power Water DNA Isolation $\mathrm{MOBIO}^{\circledR}$ and sample sequences obtained from metabarcoding were then analysed using the software QIIME (https://qiime2.org).

In Azorean lakes and thermal springs, DNA was extracted up to $24 \mathrm{~h}$ after sample collection, according to the gram-negative bacteria protocol of PureLinkTM Genomic DNA Mini Kit (Invitrogen, Carlsbad, CA, USA), followed by amplification of genes targeting 16S rDNA and cyanotoxins (Microcystin, Saxitoxin and Anatoxin-a) using conventional PCR and electrophoresis protocols (Cordeiro et al., AIL2018). All protocols used were modified from existing ones available in the scientific literature (Ouahid et al., 2005; Ballot et al., 2010; Ledreux et al., 2010; Rantala-Ylinen et al., 2011; Casero et al., 2014).

Biofilms from central Portugal and their response to multiple stressors in mesocosms were assessed through their OTUs composition in a study by Calapez et al. (AIL2018). DNA was extracted from a portion of the biofilm using PowerSoil ${ }^{\circledR}$ DNA Isolation Kit (Mobio Laboratories Inc., Carlsbad, CA, USA), followed by a PCR to amplify rDNA genes for each studied biofilm community, using a Taq DNA polymerase. The bacterial V3 region of $16 \mathrm{~S}$ was amplified with the primer pair $338 \mathrm{~F}-\mathrm{GC}$ and $518 \mathrm{R}$, the ITS1 region of rDNA of fungi using the primer pair ITS1F-GC and ITS2 and the $18 \mathrm{~S}$ gene of eukarya by using the primer pair Euk1A and Euk516r-GC. Then a Denaturing Gradient Gel Electrophoresis
(DGGE) was run for each community, conducted in a DCode system (Bio-Rad, Hercules, CA, USA). DGGE images were converted, normalized, and analysed with the software BioNumerics 7.6 (Applied Maths, Sint-Martens-Latem, Belgium) to obtain the relative abundances according to gel band intensity (OTUs).

In the Russian lake Oiskoe, planktonic microeukaryotes were assessed before and after ice-and-snow cover formation (Díaz-Quijano et al., AIL2018). The focus was set on phytoplankton and general protists, but other eukaryotic actors of the microbial loop, such as ciliates and fungi were assessed as well. General eukaryote primer pair targeting the V4 region of the small subunit 18S rRNA gene was used (Balzano et al., 2015). This is a modification of Stoeck's primer pairs (Stoeck et al., 2010), with an extra degenerate nucleotide position, which allows haptophytes to be targeted.

Total biodiversity (from microorganisms to vertebrates) has also been addressed in projects developed in Cantabria, with the addition of $16 \mathrm{~S}$ and 18S primers for prokaryotes and eukaryotes (Bact02 and Euka02 primers, respectively), besides COI for macroinvertebrates (Sainz-Bariáin et al., AIL2018).

\section{New database entries}

Continuous incorporation of data from new or updated biological surveys is essential to develop a good species database (Olenin et al., 2016). Many of the studies presented in the SS originated important new barcode data that fed different databases.

\section{Fish and invertebrates}

For marine life, core COI reference databases for the most prominent groups of Portuguese and Iberian fish and macroinvertebrates were made publicly available on BOLD systems. Regarding fish, in addition to the Portuguese marine ichthyofauna (Costa et al., 2012), reference databases have been generated for the Mediterranean (Landi et al., 2014), the North Sea and British Isles species (Knebelsberger et al., 2014). A published compilation for all European marine 
fish species is available as well (Oliveira et al., 2016). For freshwater fish species, the reference database for European species is almost complete concerning standard DNA barcodes (COI) and public data can be found in GenBank and BOLD databases. However, there is only very limited $12 \mathrm{~S}$ sequence data available that can be used as a reference to taxonomically annotate eDNA derived OTUs. Among the invertebrates there are published databases and other scattered DNA barcode contributions available for annelids, namely Polychaeta (Lobo et al., 2016; Ravara et al., 2017), for molluscs (Gastropoda: Borges et al., 2016; bivalve woodborers: Borges et al., 2012), and for crustaceans (e.g. Amphipoda; Lobo et al., 2017b).

\section{Meiofauna}

Concerning meiofauna, to the best of our knowledge, there are no specific databases. Yet, Tang and collaborators (2012) gathered a total of 12 000 sequences (generated and retrieved from GenBank) across 55 meiofaunal datasets comprising 3 taxonomic ranks ( 15 species complexes, 26 genera, and 14 higher taxa above the genus level, including orders, classes, and phyla), using either $18 \mathrm{~S}$ or COI markers.

\section{Diatoms}

For diatoms, Diat.barcode library (formely called R-Syst::diatom in Rimet et al., 2016) (https://www6.inra.fr/carrtel-collection_eng/ Barcoding-database) and was used in the studies presented at AIL2018 conducted in Portugal by Mortágua et al. (AIL 2018; 2019) and in France by Rivera et al. (AIL 2018). This database is open access and contains $18 \mathrm{~S}$ and $r b c L$ barcodes. In addition, R-Syst::diatom provides information concerning morphological diatom features (e.g., biovolumes, chloroplasts, etc.), ecological features (taxa preference to pollution) and life-forms (mobility, colony-type). The database is uploaded and curated every six months. The sequences obtained in the Russian study are not attributed to any taxocenose-specific database but should be made available to the builders of a cryophyllic diatom and green algae ribosomic RNA database at the Helmholtz Centre for Polar and Marine Research in Potsdam, Germany (shuang@awi.de).

\section{Multidisciplinary international networks}

The metagenomics is an area where extended networks tend to be formed in order to easily tackle all the fields involved, encompassing fieldwork and sample collection to laboratory procedures, taxonomic expertise and molecular analyses. This need is clear in the global distribution of authors of the SS (Fig. 1).

The University of Minho team (Portugal) has integrated the Consortium for the Barcode of Life (CBOL) from early stages and later the International Barcode of Life (iBOL) and in collaboration with the Museu Nacional de História Natural e Ciência, Instituto Português do Mar e da Atmosfera, the Portuguese Institute of Malacology, the research institutes IMAR, CIIMAR and CNC/Biocant, and the Universities of Guelph (Canada), Bangor (UK) and Vigo (Spain) works to build core reference databases for marine life.

The teams from the Universities of Aveiro and Coimbra (Portugal) have been working with INRA at Thonon-les-Bains (France) in the laboratorial treatment of periphytic biofilms, from extraction, amplification, sequencing of DNA and bioinformatic analyses. MARE team is also collaborating with CIBIO (Portugal) for the assessment of freshwater invertebrate communities and biological quality through DNA. For the FRESHING project (CIBIO/InBIO, Portugal) the laboratory procedures and the HTS (MiSeq v2, 2x250bp PE) were performed in CIBIO-UP (Portugal) while fieldwork have been done in collaboration with the company Aqualogus and the taxonomical identification at Instituto Politécnico de Bragança (Portugal). These teams, like those from Universities of Minho, Coimbra and Aveiro (Portugal), Cantabria and Barcelona (Spain), are part of the larger network of the European COST action DNAqua-Net, which among other tasks are tackling problems such as an adaptation of currently used biotic indices for metabarcoding data.

Samples from the Cantabrian coast (Spain), Gulf of Lion (South France), Polynesian ports and Spanish rivers are being processed in molec- 
ular facilities of the University of Oviedo. DNA sequencing will be done at the Massive Sequencing Service Unit from the IBBTEC (CSIC Universidad de Cantabria - Sodercan). The University of Barcelona team is currently collaborating with the University of Salford (UK) and University of Tromsø (Norway) for sequencing facilities and bioinformatics. In the Azores, all molecular laboratory work is conducted in the laboratories of the University of Azores (UAc) and CIBIO. The cyanobacteria cultures were established and maintained in BACA-Banco de Algas e Cianobactérias dos Açores (UAc), which is part of the REBECA network. The team works on this topic with the Ecotoxicology team from CIIMAR, University of Porto. In Russia, the molecular facility used was the Laboratory of Experimental Hydroecology, at the Biophysics Institute (Siberian branch of the Russian Academy of Sciences). Sequencing (Illumina MiSeq) was performed in three facilities: Konstantin V. Krutovsky lab, at the Sukachev Institute of Forest; the Centre for Collective Use of the Institute of Bioorganic Chemistry, Novosibirsk, Russia; and the company Evrogen (Moscow).

\section{MAIN FINDINGS}

The SS showed several interesting results at the technical level but also new insights for the ecology and conservation of aquatic systems.

\section{Technical aspects}

It was found that the choice of the markers to target particular primer pair can considerably influence the metabarcoding-based analyses output. For estuarine meiofaunal. up to $85 \%$ of the species constituting a mock community were detected by using a combination of 3 primer pairs targeting the COI region, while only 30 to $60 \%$ were recovered by using any primer set alone (Hollatz et al., 2017; Fais et al., AIL218). Also, the amount of starting material from the sample for eDNA extraction is critical for a comprehensive assessment of meiofaunal communities in estuarine ecosystems.

The use of preservative ethanol from field samples seems to be a promising solution for macroinvertebrate biodiversity assessment, with faster processing of samples in the lab for DNA metabarcoding. However, the results are sensitive to various laboratory procedures, namely DNA extraction methods and/or the storage and collection timing of preservative ethanol (Martins et al., AIL2018).

\section{Ecology and conservation}

Molecular analyses in aquatic ecosystems brought not only new information but also new questions. DNA barcoding studies on Portuguese marine life have been revealing numerous cases of comparatively high intra-specific divergences, suggesting the existence of considerable hidden diversity and putative cryptic species across diverse marine taxa, including fish and major groups of invertebrates (Costa et al., 2012, Landi et al., 2014, Lobo et al., 2016, 2017a, Oliveira et al., 2016). These findings suggest that populations of marine organisms may be much more structured than previously thought, calling for a continuous effort on the description of the hidden diversity and further completion of the reference databases. In order to improve the efficiency of amplification of COI barcodes from marine macrozoobenthos, Lobo et al. (2013) developed a new pair of degenerate primers with a broad scope of amplification success across a phylogenetically diverse range of marine metazoan taxa.

In the very first study based on molecular data of freshwater diatom communities in Portugal, the total number of diatom taxa identified was 125 from 88 river samples which corresponded to about $41 \%$ of the number of taxa identified by using the light microscope (Mortágua et al., AIL2018; Mortágua et al., 2019). These results, somewhat unexpected, were in accordance with results registered in studies performed in other countries (Vasselon et al., 2017b; Rivera et al., 2018 and Keck et al., 2018). A possible explanation might be the high number of unassigned reads, which is a consequence of the incompleteness of the reference database.

The molecular approach was also found important in the detection of new introductions of fishes and tracking introduction histories, which can be relevant for designing proper management plans. It is the case of the species $P$. phoxinus that 
was recorded for the first time in the Douro Basin. This species can be easily misidentified as other species from the same genus when using only morphological identifications in the field.

The eDNA and metabarcoding approaches were found efficient to obtain accurate baseline information to be used in conservation planning and ongoing management of coastal lagoons in the south of France. Despite their different status of conservation within Natural Parks, Reserves or Natura 2000 Network, they are already contaminated with non-indigenous species, some of them already described as invasive species.

New records of cyanobacteria species presence were detected in the Azores through molecular analyses (Cordeiro et al., AIL2018). In addition, some of the sampled lakes cyanotoxins production potential was confirmed, mainly associated with eutrophication and anthropogenic effects, which shows the potential of molecular tools for monitoring cyanotoxin risk in aquatic systems.

In Russia, a unique dataset of early winter lake water microbial communities was produced as winter dynamics are usually out of the scope of limnological studies in Siberia, due to the harsh fieldwork conditions (Diaz-de-Quijano et al., AIL2018). The Cryptomycota clade LKM11, which was previously found in ice-covered lakes of Antarctica (Rojas-Jimenez et al., 2017), represented up to $6-10 \%$ of the reads in intermediate and deep layers of the water column of the ice-covered Oiskoe lake. Metabarcoding of microbial but also macroscopic communities enabled an easier calculation of phylogenetic diversity metrics, and testing hypotheses on the ecological mechanisms governing community assemblages.

\section{MAJOR DRAWBACKS}

Different technical drawbacks were signalized in the SS, in spite of the potential advantages of molecular approaches in biodiversity and ecological assessment of aquatic ecosystems.

\section{Taxonomic gaps}

In the SS it was often referred to the existence of taxonomic gaps in the reference databases when considering local fauna. One example is the study in the Lima estuary and in the Tua river in Portugal with benthic invertebrates, where a fair number of OTUs could not be assigned to phylum or other lower taxonomic rank due to the primers used for targeting the COI region (Mortágua et al., 2019). A similar issue was reported for the diatoms as previously referred, in spite of the large database and diatom cultures existing in Thonon-les-Bains, INRA, with a high number of unassigned reads (67 $\%)$. The increase in the number of diatom barcodes in reference databases will allow for a complete study of diversity, namely in what concerns to rare taxa. In some cases, databases are not sufficient for assigning species and they must be assigned at genus level; in these cases, previous taxonomic work is necessary. In the French coastal lagoons, only ca. $10 \%$ of reads obtained were identified to the species level and those that could not be described to the species level had multiple best BLAST hits or the best BLAST hit had no species-level information available. In addition, local databases covering intra-specific variability are important, especially when geographical barriers can lead to high intra-specific variability (e.g., Douro River Basin).

\section{Extraction of eDNA}

Protocols need further adjustments and should be adapted to the environments and types of samples (e.g., biofilms scrapings or preservative liquid of bulk samples instead of water). eDNA extraction was the biggest setback. This was found through the development of the work with cyanobacteria as they have a wide range of morphological characteristics, like mucilage sheaths (Codd et al., 2017), that makes DNA extraction more complicated. Different methods were tested to improve cell lysis, like sonication, enzymatic lysis and readjustments of temperature and incubation time (Kim et al., 2009). Similar results were found using ethanol from the preservation of macroinvertebrate samples where different DNA extraction methods retrieved different species diversity across time.

\section{Amount of environmental sample}

The amount of sample needed for good DNA extraction can be harder to determine since it 
depends not only on the type of sample (e.g., water, sediment) but also on the study site. For example, in eutrophic lakes, there is a higher abundance and diversity of phytoplankton, while in thermal springs there is lower abundance and diversity of phytoplankton (Cordeiro et al., AIL2018). Preliminary research employing metabarcoding on eDNA extracted from sediments at an estuarine site in the North of Portugal revealed that more OTUs assigned to meiofauna were recovered by using higher amounts of sediment samples (Fais et al., AIL2018).

\section{Genetic markers}

Different genetic markers and bioinformatics pipelines must be considered to obtain the most accurate results. For fish, it is hard to find a single nuclear marker with enough resolution to delimit closely related species (Filipe et al., AIL2018). Despite the appropriateness of COI and CytB markers for the majority of the species, some genera such as Achondrostoma or Cobitis can represent a bigger problem to identify the specimens taxonomically to species-level.

\section{Cost of sequencing}

The cost of HTS is still significantly high and highly variable, which limits their present use in large monitoring programs. Especially in Russia, the purchase of reagents and materials from western countries might take up to 6 months and cost up to twice their price in the West, which makes it difficult to match financing and project calendars, when it comes to using metabarcoding in a particular project.

\section{CONCLUSIONS}

Studies presented in AIL2018 meeting enhanced the importance and applicability of molecular techniques in environmental studies, towards fast and significant information acquisition. This information can be used in biodiversity and ecological quality assessments, conservation and management of aquatic water bodies.

During the SS, it became clear that molecular tools, and particularly the metabarcoding approach, could provide fine-scale taxonomical resolution data, contribute to detect new invasions and allow for unveiling hidden biodiversity resulting from low-abundance, small sizes and poor-developmental stages.

Yet, a lot of work and investment is still needed before molecular tools can be used routinely in monitoring programs, namely in the completion of databases, optimization and standardization of both laboratory and field protocols, in automation in sample handling and bioinformatics analyses and ultimately in reducing analyses costs. Moreover, considering the adaptation to the WFD, which requires reaching a quality status that could actually replace the existing ones based on taxonomy, it is necessary to establish new reference values for different types of rivers and other water bodies (Feio et al., 2014) or check existing ones with molecular data, and establish clear responses to disturbance gradients (Filipe et al., 2018). This however, might soon become a reality for diatoms, macroinvertebrates and fish. The relatively well-developed taxonomy and autoecology of diatoms make them an ideal case to compare genetic, morphological and ecological determination of species. On the other hand, by the use of primer pairs that target a phylogenetic range wider than diatoms, (e.g., targeting eukaryotes) studies could include a wider spectrum of autoecologies with more power to inform about the ecological state of aquatic ecosystems.

Despite most studies presented, in the special session being from Europe, the perspectives, main findings and drawbacks are likely to be common to other geographic areas across the globe. Therefore, we expect this review to be useful to other researchers across the world, dealing with molecular tools for ecological and biodiversity assessment of aquatic ecosystems.

\section{ACKNOWLEDGEMENTS}

We are grateful to all participants of the special session "The use of molecular tools in ecological and biodiversity assessment of aquatic ecosystems" for the productive discussions during the AIL 2018 meeting (XIX Iberian Association of Limnology meeting in Coimbra (Portugal, June 2018). M.J. Feio is supported by MARE strategic 
program (UID/MAR/04292/2013); SFP Almeida is supported by GeoBioTec strategic program UID/GEO/04035/2019. R. Cordeiro was supported by a Ph.D. Grant (M3.1.a/F/017/2011) from Fundo Regional da Ciência e Tecnologia (FRCT); A.F. Filipe and A. Garcia-Raventos were supported by FRESHING Project "Next-generation biomonitoring: freshwater bioassessment and species conservation improved with metagenomics" funded by the Portuguese Foundation for Science and Technology (FCT) and COMPETE (PTDC/AAG-MAA/2261/2014 - POCI-01-0145FEDER-356 016824); F.M.S. Martins was supported by a FCT PhD grant (SFRH/BD/ 104703/2014); A.R. Calapez was supported by a grant from the FCT-PhD programme FLUVIO $(\mathrm{PD} \backslash \mathrm{BD} \backslash 52510 \backslash 2014)$; A.M. Pujante acknowledges the BIOWAT-KIT_E!11892 Eurostars project; Maria Fais and Sofia Duarte were supported, respectively, by a PhD (SFRH/BD/ $113547 / 2015)$ and a post-doc fellowship (SFRH/BPD/109842/2015), from FCT; and C. Múrria acknowledges the Fundació Aigües de Barcelona for funding his research.

\section{REFERENCES}

ALBA-TERCEDOR, J., P. JÁIMEZ-CUÉLLAR, M. ÁlVAREZ, J. AVILÉS, N. BONADA, J. CASAS, A. MELLADO, M. ORTEGA, I. PARDO, N. PRAT, M. RIERADEVALL, S. ROBLES, C.E. SÁINZ-CANTERO, A. SÁNCHEZ-ORTEGA, M.L. SUÁREZ, M. TORO, M.R. VIDAL-ABARCA, S. VIVAS \& C. ZAMORA-MUÑOZ. 2002. Caracterización del estado ecológico de ríos mediterráneos ibéricos mediante el índice IBMWP (antes BMWP'). Limnetica, 21: 175-185.

ALVES, A. S., A. CAETANO, J. L. COSTA, M. J. COSTA \& J. C. MARQUES. 2015. Estuarine intertidal meiofauna and nematode communities as indicator of ecosystem's recovery following mitigation measures. Ecological Indicators, 54: 184-196. DOI: 10.1016/j. ecolind.2015.02.013

ANASTÁCIO, P. M., F. RIBEIRO, C. CAPINHA, F. BANHA, M. GAMA, A. F. FILIPE, R. REBELO. \& R. SOUSA. 2018. Non-native freshwater fauna in Portugal: a review. Science of the Total Environment, 650: 1923-1934. DOI: 10.1016/j.scitotenv 2018.09.251

ANTUNES, P. \& F.C. RODRIGUES. 2011. Azores volcanic lakes: factors affecting water quality. Water Quality: Current Trends and Expected Climate Change Impacts. Proceedings of symposium $\mathrm{HO} 4$ held during IUGG2011, Melbourne, Australia, July 2011, IAHS Publ. 348.

ARDURA, A., A. R. LINDE, J. C. MOREIRA \& E. GARCIA-VAZQUEZ. 2010. DNA barcoding for conservation and management of Amazonian commercial fish. Biological Conservation, 143: 1438e1443. DOI: 10.1016/ j.biocon.2010.03.019

ARDURA, A., S. PLANES \& E. GARCIA-VAZQUEZ. 2011. Beyond biodiversity: fish metagenomes. PLoS One 6, e22592. DOI: 10.1371/journal.pone.0022592

ARDURA, A., A. ZAIKO, J. L. MARTINEZ, A. SAMUILOVIENE, Y. J. BORRELL \& E. GARCIA-VAZQUEZ. 2015a. Environmental DNA evidence of transfer of North Sea molluscs across tropical waters through ballast water. Journal of Molluscan Studies, 81: 495e501. DOI: 10.1093/mollus/eyv022

ARDURA, A., A. ZAIKO, J. L. MARTINEZ, A. SAMULIOVIENE, et al., 2015b. eDNA and specific primers for early detection of invasive species, a case study on the bivalve Rangia cuneata, currently spreading in Europe. Marine and Environmental Research, 112: 48e55. DOI: 10.1016/j.marenvres.2015.09.013

ARDURA, A. \& S. PLANES. 2017. Rapid assessment of non-indigenous species in the era of the eDNA barcoding: A Mediterranean case study. Estuarine Coastal and Shelf Science, 188: 81-87. DOI: 10.1016/j.ecss.2017.02.004

ARDURA, A. 2018. The application of eDNA and HTS as tools to analyze the biodiversity in fragile ecosystems. XIX Meeting of the Iberian Association of Limnology, 24-29 June, Coimbra, Portugal.

ARDURA, A. \& A. ZAIKO. 2018. PCR-based assay for Mya arenaria detection from marine environmental samples and tracking its invasion in coastal ecosystems. Journal of Nature Conservation, 43: 1-7. DOI: 10.1016/ j.jnc.2018.02.007 
AYLAGAS, E., A. BORJA, X. IRIGOIEN \& N. RODRIGUEZ-EXPELETA. 2016. Benchmarking DNA metabarcoding for biodiversity-based monitoring and assessment. Frontiers in Marine Science, 3: 1-12. DOI: 10.3389/fmars.2016.00096

BALLOT, A., J. FASTNER, M. LENTZ \& C. WIEDNER. 2010. First report of anatoxin-a-producing cyanobacterium Aphanizomenon issatschenkoi in northeastern Germany. Toxicon, 56: 964-971. DOI: 10.1016/j.toxicon. 2010.06.021

BORGES, L. M. S., H. SIVRIKAYA, A. LE ROUX, R. SHIPWAY, S. M. CRAGG \& F. O. COSTA. 2012. Investigating the taxonomy and systematics of marine wood borers (Bivalvia: Teredinidae) combining evidence from morphology, DNA barcodes and nuclear locus sequences. Invertebrate Systematics, 26: 572-582. DOI: 10.1071/IS12028

BORGES, L. M. S., C. HOLLATZ, J. LOBO, A. M. CUNHA, A. P. VILELA, G. CALADO, R. COELHO, A. C. COSTA, M. G. FERREIRA, M. H. COSTA \& F. O. COSTA. 2016. With a little help from DNA barcoding: investigating the diversity of Gastropoda from the Portuguese coast. Scientific Reports, 6: 20226.

CALAPEZ, A. R., C. ELIAS, A. PEREIRA, A. ALVES, S. ALMEIDA \& M. J. FEIO. 2018. Molecular evidences of biofilm responses to multiple-stressors: community shifts induced by flow stagnation, organic loads and grazing. XIX Conference of the Iberian Association of Limnology, 24-29 June, Coimbra, Portugal

CASERO, M., A. BALLOT, R. AGHA, A. QUESADA \& S. CIRÉS. 2014. Characterization of saxitoxin production and release and phylogeny of sxt genes in paralytic shellfish poisoning toxin-producing Aphanizomenon gracile. Harmful Algae, 37: 28-37. DOI: 10.1016/j.hal. 2014.05.006

CATAUDELlA, S., D. CROSETTI \& F. MASSA. 2015. Mediterranean coastal lagoons: sustainable management and interactions among aquaculture, capture fisheries and the environment. General Fisheries Commission for the Mediterranean. Studies and Reviews, 95, I.

CHAPMAN, P. M. 2012. Management of coastal lagoons under climate change. Estuarine, Coastal and Shelf Science, 110: 32-35. DOI: 10.1016/j.ecss.2012.01.010

CLUSA L., A. ARDURA, F. GOWER, L. MIRALLES, V. TSARTSIANIDOU, A. ZAIKO \& E. GARCIA-VAZQUEZ. 2016. An easy phylogenetically informative method to trace the globally invasive Potamopyrgus mud snail from river's eDNA. PLoS One 11, e0162899. DOI: 10.1371/journal.pone.0162899

CODD, G. A., J. MERILUOTO \& J. S. METCALF. 2017. Introduction: Cyanobacteria, Cyanotoxins, their human impact, and risk management. In MERILUOTO, J., SPOOF, L. \& G.A. CODD, (Eds.) Handbook of Cyanobacterial Monitoring and Cyanotoxin Analysis. (pp. 3-8) West Sussex, UK: John Wiley \& Sons, Ltd.

COISSAC, E., T. RIAZ \& N. PUILLANDRE, .2012. Bioinformatic challenges for DNA metabarcoding of plants and animals. Molecular Ecology, 21: 1834-1847. DOI: 10.1111/j. 1365-294X.2012.05550.X

CORDEIRO, R. I., R. LUZ, M. PIMENTEL, A. CARDOSO, V. VASCONCELOS, V. GONÇALVES \& A. FONSECA. 2018. Azorean extremophile cyanobacteria and their cyanotoxin production potential. XIX Meeting of the Iberian Association of Limnology, Coimbra, Portugal, 24-29 June, Coimbra, Portugal

COSTA F. O., M. LANDI, R. MARTINS, M. H. COSTA, M. E. COSTA, M. CARNEIRO, M. J. ALVES, D. STEINKE \& G. R. CARVALHO. 2012. A ranking system for reference libraries of DNA barcodes: Application to marine fish species from Portugal. PLoS One 7, e35858. DOI: 10.1371/journal.pone.0035858

DEAGLE, B. E., S. N. JARMAN, E. COISSAC, F. POMPANON \& P. TABERLET. 2014. DNA metabarcoding and the cytochrome c oxidase subunit I marker: not a perfect match. Biology letters, 10: 20140562. DOI: 10.1098/ rsbl.2014.0562

DEINER, K., H. M. BIK, E. MÄCHLER, M. SEYMOUR, A. LACOURSIÈRE-ROUSSEL, F. ALTERMATT, S. CREER, I. BISTA, D. M. LODGE, N. DE VERE \& M. E. PFRENDER. 2017. Environmental DNA metabarcod- 
ing: transforming how we survey animal and plant communities. Molecular ecology, 26: 5872-5895. DOI: $10.1111 / \mathrm{mec} .14350$

DEVLOO-DELVA F., L. MIRALLES, A. ARDURA, Y. J. BORRELL, I. PEJOVIC, V. TSARTSIANIDOU \& E. GARCIA-VAZQUEZ. 2016. Detection and characterisation of the biopollutant Xenostrobus securis (Lamarck 1819) Asturian population from DNA Barcoding and eBarcoding. Marine Pollution Bulletin, 105: 23-29. DOI: 10.1016/j.marpolbul. 2016.03.008

DIAZ-DE-QUIJANO, D., O. KOLMAKOVA, M. TRUSOVA \& E. A. IVANOVA. 2018. Phytoplankton community before and after ice-and-snow cover formation in a South Central Siberian mountain lake. XIX Meeting of the Iberian Association of Limnology, 24-29 June, Coimbra, Portugal.

ELBRECHT, V. \& F. LEESE. 2017. PrimerMiner: an $\mathrm{R}$ package for development in silico validation of DNA metabarcoding primers. Methods in Ecology and Evolution, 8: 622-626. DOI: 10.1111/2041-210X.12687

ELVIRA, B. \& A. ALMODÓVAR. 2001. Freshwater fish introductions in Spain: facts and figures at the beginning of the 21st century. Journal of fish Biology, 59: 323-331. DOI: 10.1111/j.1095-8649.2001.tb01393.x

EUROPEAN UNION. 2000. Directive 2000/60/EC of October 23, 2000, of the European parliament and of the council establishing a framework for community action in the field of water policy. Official J Eur Community L327, 1-72.

FAIS, M., S. DUARTE, R. SOUSA, M. HAJIBABAEI, C. A. CANCHAYA \& F. O. COSTA. 2018. Metabarcoding of meiobenthic estuarine communities: optimization of protocols. XIX Meeting of the Iberian Association of Limnology, 24-29 June, Coimbra, Portugal.

FEIO, M. J., F. C. AGUIAR, S. F. P. ALMEIDA, J. FERREIRA, M. T. FERREIRA, C. ELIAS, S. R. S. SERRA, A. BUFFAGNI, J. CAMBRA, C. CHAUVIN, F. DELMAS, G. DÖRFLINGER, S. ERBA, N. FLOR, M. FERRÉOL, M. GERM, L. MANCINI, P. MANOLAKI, S. MARCHEGGIANI, M. R. MINCIARDI, A.MUNNÉ, E. PAPASTERGIADOU, N. PRAT, C. PUCCINELLI, J.
ROSEBERY, S. SABATER, S. CIADAMIDARO, E. TORNÉS, I. TZIORTZIS, G. URBANIC \& C. VIEIRA. 2014. Least disturbed conditions for European Mediterranean rivers. Science of the Total Environment, 476-477: 745-756. DOI: 10.1016/j.scitotenv. 2013.05.056

FICETOLA, G. F., E. COISSAC, S. ZUNDEL, T. RIAZ, W. SHEHZAD, W. BESSIÈRE, P. TARBERLET \& F. POMPANON. 2010. An In silico approach for the evaluation of DNA barcodes. BMC Genomics, 11: 434. DOI: 10.1186/1471-2164-11-434

FILIPE, A. F., M. J. FEIO, A. GARCIA-RAVENTÓS, J. P. RAMIÃO, G. PACE, F. M. S. MARTINS \& M. F. MAGALHÃES. 2018. The European Water Framework Directive facing current challenges: recommendations for a more efficient biological assessment of inland surface waters. Inland Waters: DOI: $10.1080 / 20442041.2018 .1494973$

FILIPE, A. F., F. M. S. MARTINS, J. P. RAMIÃO, A. GARCIA-RAVENTÓS, J. PAUPÉRIO, S. FERREIRA, V. HERMOSO, M. T. MONAGHAN, M. F. MAGALHÃES \& P. BEJA. 2018. Delineating freshwater monitoring networks using eDNA metabarcoding. XIX Meeting of the Iberian Association of Limnology, 24-29 June, Coimbra, Portugal.

GARCIA-RAVENTÓS, A., F. M. S. MARTINS, M. F. MAGALHÃES, J. P. RAMIÃO, M. FERREIRA, S. CARONA S, F. CARVALHO, R. SOUSA, E. FROUFE, A. TEIXEIRA, S. VARANDAS, M. LIMA, P. BEJA \& A. F. FILIPE. 2018. Multiple introductions and first record of Phoxinus phoxinus in the Douro Basin revealed by molecular data. XIX Meeting of the Iberian Association of Limnology, 24-29 June, Coimbra, Portugal.

GONÇALVES, V., R. LUZ, R. CORDEIRO, E. XAVIER, A. FONSECA \& A. I. NETO. 2018. Azorean Bank of Algae and Cyanobacteria: a resource for biodivertity assessment and biotechological applications. XIX Meeting of the Iberian Association of Limnology, 24-29 June, Coimbra, Portugal.

HAASE, P., S. U. PAULS, K. SCHINDEHÜTTE \& A. SUNDERMANN. 2010. First audit of 
macroinvertebrate samples from an EU Water Framework Directive monitoring program: Human error greatly lowers precision of assessment results. Journal of the North American Benthological Society, 29: 1279-1291. DOI: $10.1899 / 09-183.1$

HAENEL, Q., O. HOLOVACHOV, U. JONDELIUS, P. SUNDBERG \& S. BOURLAT. 2017. NGS-based biodiversity and community structure analysis of meiofaunal eukaryotes in shell sand from Hållö island, Smögen, and soft mud from Gullmarn Fjord, Sweden. Biodiversity Data Journal, 5, e12731. DOI: 10.3897/BDJ.5.e12731

HAJIBABAEI, M., J. L. SPALL, S. SHOKRALLA \& S. VAN KONYNENBURG. 2012. Assessing biodiversity of a freshwater benthic macroinvertebrate community through non-destructive environmental barcoding of DNA from preservative ethanol. BMC ecology, 12: 28. DOI: $10.1186 / 1472-6785-12-28$

HEBERT, P. D., A. CYWINSKA, S. L. BALL \& J. R. DEWAARD. 2003. Biological identifications through DNA barcodes. Proceedings of the Royal Society: Biological Sciences, 270: 313-321. DOI: 10.1098/rspb.2002.2218

HIGGINS, R. P. \& H. THIEL, 1988. Introduction to the study of Meiofauna. Smithsonian Institution Press, 488 pp.

HILBISH, T. J., A. MULLINAX, S. I. DOLVEN \& A. MEYER. 2000. Origin of the antitropical distribution pattern in marine mussels (Mytilus spp.): routes and timing of transequatorial migration. Marine Biology, 136: 69-77. DOI: $10.1007 / \mathrm{s} 002270050$

HOLLATZ C., B. R. LEITE, J. LOBO, H. FROUFE, C. EGAS \& F. O. COSTA. 2017. Priming of a DNA metabarcoding approach for species identification and inventory in marine microbenthic communities. Genome, 60: 260-271. DOI: 10.1139/gen-2015-0220

KECK, F., V. VASSELON, F. RIMET, A. BOUCHEZ \& M. KAHLERT. 2018. Boosting DNA metabarcoding for biomonitoring with phylogenetic estimation of OTUs' ecological profiles. Molecular Ecology Resources, 18: 1299-1309. DOI: 10.1111/1755-0998.12919

KELLY, M., N. BOONHAM, S. JUGGINS, P. KILLE, D. MANN, D. PASS, M. SAPP, S.
SATO \& R. GOLVER. 2018. A DNA based diatom metabarcoding approach for Water Framework Directive classification of rivers. Report SC140024/R. Environment Agency, Bristol, UK.

KIM, I. S., G. H. NGUYEN, S. KIM, J. LEE \& H.-W. YU. 2009. Evaluation of Methods for Cyanobacterial Cell Lysis and Toxin (Microcystin-LR) Extraction Using Chromatographic and Mass Spectrometric Analyses. Environmental Engineering Research, 14: 250-254. DOI: 10.4491/eer.2009.14.4.250

KNEBELSBERGER T., M. LANDI, H. NEUMANN, M. KLOPPMANN, A. SELL, P. D. CAMPBELL, S. LAAKMANN, M. J. RAUPACH, G. R. CARVALHO \& F. O. COSTA. 2014. A reliable DNA barcode reference library for the identification of the North European shelf fish fauna. Molecular Ecology Resources, 14: 1060-1071. DOI: 10.1111/17550998.12238

LANDI, M., M. DIMECH, M. ARCULEO, G. BIONDO, R. MARTINS, M. CARNEIRO, G. R. CARVALHO, S. L BRUTTO \& F. O. COSTA. 2014. DNA barcoding for species assignment: the case of Mediterranean marine fishes. PLoS ONE, 9, e106135. DOI: 10.1371/ journal.pone. 0106135

LEDREUX, A., S. THOMAZEAU, A. CATHERINE, C. DUVAL, C. YÉPRÉMIAN, A. MARIE \& C. BERNARD. 2010. Evidence for saxitoxins production by the cyanobacterium Aphanizomenon gracile in a French recreational water body. Harmful Algae, 10: 88-97. DOI: 10.1016/j.hal.2010.07.004

LEESE, F., F. ALTERMATT, A. BOUCHEZ, T. EKREM, D. HERING, P. MERGEN, J. PAWLOWSKI, J. PIGGOTT, K. ABARENKOV, P. BEJA, L. BERVOETS, P. BOETS, A. BONES, A. BORJA, K. BRUCE, J. CARLSSON, E. COISSAC, F. COSTA, et al. 2016. DNAqua-Net: Developing new genetic tools for bioassessment and monitoring of aquatic ecosystems in Europe. Research Ideas and Outcomes, 2, e11321. DOI: 10.3897/ rio.2.e11321

LIN, S., H. ZHANG, Y. HOU, Y. ZHUANG \& L. MIRANDA. 2009. High-level diversity of dinoflagellates in the natural environment, 
revealed by assessment of mitochondrial cox1 and cob genes for dinoflagellate DNA barcoding. Applied and environmental microbiology, 75: 1279-1290. DOI: 10.1128/AEM.01578-08

LOBO, J., P. M. COSTA, M. A. L. TEIXEIRA, M. S. FERREIRA, M. H. COSTA \& F. O. COSTA. 2013. Enhanced primers for amplification of DNA barcodes from a broad range of marine metazoans. BMC Ecology, 13: 34. DOI: $10.1186 / 1472-6785-13-34$

LOBO, J., M. A. L. TEIXEIRA, L. M. S. BORGES, M. S. G. FERREIRA, C. HOLLATZ, P. A. GOMES, R. SOUSA, A. RAVARA, M. H. COSTA \& F. O. COSTA. 2016. Starting a DNA barcode reference library for shallow water polychaetes from the southern European Atlantic coast. Molecular Ecology Resources, 16: 298-313. DOI: 10.1111/1755-0998.12441

LOBO, J., S. SHOKRALLA, M. H. COSTA, M. HAJIBABAEI \& F. O. COSTA. 2017a. DNA metabarcoding for highthroughput monitoring of estuarine macrobenthic communities. Scientific Reports, 7: 15618. DOI: 10.1038/ s41598-017-15823-6

LOBO, J., M. S. FERREIRA, I. C. ANTUNES, M. A. L. TEIXEIRA, L. M. S. BORGES, R. SOUSA, P. A. GOMES, M. H. COSTA, M. R. CUNHA \& F. O. COSTA. 2017b. Contrasting morphological and DNA barcode suggested species boundaries among shallow-water amphipod fauna from the southern European Atlantic coast. Genome, 60: 147-157. DOI: 10.1139/gen-2016-0009

MARTINS, F. M. S., M. GALHARDO, A. TEIXEIRA, P. PINHEIRO, A. F. FILIPE, P. C. ALVE \& P. BEJA. 2018. Improving freshwater biodiversity assessment: application of molecular tools on preservative ethanol from macroinvertebrate bulks. XIX Meeting of the Iberian Association of Limnology, 24-29 June, Coimbra, Portugal.

MARTINS, F. M., GALHARDO, M., FILIPE, A. F., TEIXEIRA, A., PINHEIRO, P., PAUPÉRIO, J., ALVES, P.C. \& BEJA, P. 2019. Have the cake and eat it: Optimizing nondestructive DNA metabarcoding of macroinvertebrate samples for freshwater biomonitoring. Molecular Ecology Resources.
DOI: 10.1111/1755-0998.13012

MINCHIN, D., S. OLENIN, T. K. LIU, M. CHENG \& S. C. HUANG. 2016. Rapid assessment of target species: byssate bivalves in a large tropical port. Marine Pollution Bulletin, 112: 177e182. DOI: 10.1016/j.marpolbul.2016. 08.023

MIYA, M., Y. SATO, T. FUKUNAGA, T. SADO, J. Y. POULSEN, K. SATO \& M. KONDOH. 2015. MiFish, a set of universal PCR primers for metabarcoding environmental DNA from fishes: detection of more than 230 subtropical marine species. Royal Society open science, 2: 150088. DOI: 10.1098/rsos.150088 MORTÁGUA, A., V. VASSELON, R. OLIVEIRA, C. ELIAS, C. CHARDON, A. BOUCHEZ, F. RIMET, M. J FEIO \& S. F. P. ALMEIDA. 2018. DNA metabarcoding approach as a complementary technique for assessment of Portuguese rivers using diatoms. XIX Meeting of the Iberian Association of Limnology, 24-29 June, Coimbra, Portugal.

MORTÁGUA, A., V. VASSELON, R. OLIVEIRA, C. ELIAS, C. CHARDON, A. BOUCHEZ, F. RIMET, M. J FEIO \& S. F. P. ALMEIDA. 2019. Applicability of DNA metabarcoding approach in the bioassessment of Portuguese rivers using diatoms. Ecological indicators, 106: 1054470. DOI: 10.1016/j. ecolind.2019.105470

MUNNÉ, A. \& N. PRAT. 2004. Defining river types in a Mediterranean area: a methodology for the implementation of the EU Water Framework Directive. Environmental management, 34: 711-729. DOI: 10.1016/j.ecolind. 2019.10547010.1007/s00267-003-0098-y

MUNNÉ, A. \& N. PRAT. 2011. Effects of Mediterranean climate annual variability on stream biological quality assessment using macroinvertebrate communities. Ecological Indicators, 11: 651-662. DOI: 10.1016/j.ecolind.2010. 09.004

MÚRRIA, C., O. S. WANGENSTEEN, S. SOMMA, L. O. S. VÄISÄNEN, M. A. ARNEDO \& N. PRAT. 2018. Metagenomic analysis of macroinvertebrates along the Llobregat river (NE-Iberian Peninsula) and its use for biomonitoring. XIX Meeting of the Iberian Association of Limnology, 24-29 
June, Coimbra, Portugal.

MÚRRIA, C., L. O. S. VÄISÄNEN, S. SOMMA, O. S. WANGENSTEEN, M. A. ARNEDO \& N. PRAT. 2020. Towards an Iberian DNA barcode reference library of freshwater macroinvertebrates and fishes. Limnetica, 39 (1), 73-92. DOI: 10.23818/limn.39.06

OLENIN, S., H. OJAVEER, D. MINCHIN \& R. BOELENS. 2016. Assessing exemptions under the ballast water management convention: preclude the Trojan horse. Marine Pollution Bulletin, 103: 84e92. DOI: 10.1016/j. marpolbul.2015.12.043

OLIVEIRA, L. M., T. KNEBELSBERGER, M. LANDI, P. SOARES, M. J. RAUPACH \& F. O. COSTA. 2016. Assembling and auditing a comprehensive DNA barcode reference library for European marine fishes. Journal of Fish Biology, 89: 2741-2754. DOI: 10.1111/jfb. 13169

OUAHID, Y., G. PÉREZ-SILVA \& F. DEL CAMPO. 2005. Identification of potentially toxic environmental Microcystis by individual and multiple PCR amplification of specific microcystin synthetase gene regions. Environmental Toxicology, 20: 235-242. DOI: 10.1002/ tox.20103

PAWLOWSKI, J., F. LEJZEROWICZ, L. APOTHELOZ-PERRET-GENTIL, J. VISCO \& P. ESLING. 2016. Protist metabarcoding and environmental biomonitoring: time for change. European Journal of Protistology, 55: 12-25. DOI: 10.1016/j.ejop.2016.02.003

PEARSON, L. A. \& B. A. NEILAN. 2008. The molecular genetics of cyanobacterial toxicity as a basis for monitoring water quality and public health risk. Current Opinion in Biotechnology, 19: 281-288. DOI: 10.1016/j. copbio.2008.03.002

PUJANTE, A. M., R. GONZÁLEZ, V. ROJO, J. VIERNA, M. NIEMINEN \& M. HAMMERS. 2018. Development of novel metabarcoding approach to benthic macroinvertebrates species identification. XIX Meeting of the Iberian Association of Limnology, 24-29 June, Coimbra, Portugal.

RANTALA-YLINEN, A., S. KÄNÄ, H. WANG, L. ROUHIAINEN, M. WAHLSTEN, E. RIZZI, K. BERG, M. GUGGER \& K. SIVO-
NEN. 2011. Anatoxin-a Synthetase Gene Cluster of the Cyanobacterium Anabaena sp. Strain 37 and Molecular Methods to Detect Potential Producers. Applied Environmental Microbiology, 77: 7271-7278. DOI: 10.1128/ AEM.06022-11

RATNASINGHAM, S. \& P. D. N. HEBERT. 2013. A DNA-BASED REGISTRY FOR ALL ANIMAL SPECIES: The Barcode Index Number (BIN) System. PLoS ONE, 8: e66213. DOI: 10.1371/journal. pone.0066213

RAVARA, A., D. RAMOS, M. A. L. TEIXEIRA, F. O. COSTA \& M. R. CUNHA. 2017. Taxonomy, distribution and ecology of the order Phyllodocida (Annelida, Polychaeta) in deep-sea habitats around the Iberian margin. Deep-Sea Research II, 137: 207-231. DOI: 10.1016/j.dsr2.2016.08.008

RIMET, F., P. CHAUMEIL, F. KECK, L. KERMARREC, V. VASSELON, M. KAHLERT \& A. BOUCHEZ. 2016. R-Syst::diatom: An open-access and curated barcode database for diatoms and freshwater monitoring. Database, 1-21. DOI: 10.1093/database/baw016

RIUS, M., X. TURON, G. BERNARDI, F. A. M. VOLCKAERT \& F. VIARD. 2014. Marine invasion genetics: from spatio-temporal patterns to evolutionary outcomes. Biological Invasions, 17: 869-885. DOI: 10.1007/s10530014-0792-0

RIVERA, S. F., V. VASSELON, K. TAPOLCZAI, F. RIMET \& A. BOUCHEZ. 2018. Diatom metabarcoding for biomonitoring: an overview. XIX Meeting of the Iberian Association of Limnology, Coimbra, Portugal, 24-29 June, Coimbra, Portugal.

RIVERA, S. F., V. VASSELON, S. JACQUET, A. BOUCHEZ, D. ARIZTEGUI, \& F. RIMET. 2018. Metabarcoding of lake benthic diatoms: from structure assemblages to ecological assessment. Hydrobiologia, 807: 37-51. DOI: 10.1007/s10750-017-3381-2

SINZIANA F. RIVERA, VALENTIN VASSELON, AGNÈS BOUCHEZ, FRÉDÉRIC RIMET. 2020. Diatom metabarcoding applied to large scale monitoring networks: Optimization of bioinformatics strategies using Mothur software. Ecological indicators, (109). DOI: 10.1016/j.ecolind.2019.105775 
ROJAS-JIMENEZ, K., C. WURZBACHER, E. C. BOURNE, A. CHIUCHIOLO, J. C. PRISCU \& H. P. GROSSART. 2017. Early diverging lineages within Cryptomycota and Chytridiomycota dominate the fungal communities in ice-covered lakes of the McMurdo Dry Valleys, Antarctica. Scientific Reports 7: 1-11. DOI: 10.1038/s41598-017-15598-w

SÁINZ-BARIÁIN, M., D. VIEITES \& J. BARQUÍN. 2018. The use of eDNA in river ecosystems to design environmental indices. XIX Meeting of the Iberian Association of Limnology, 24-29 June, Coimbra, Portugal.

SALMASO, N., C. BERNARD, J.-F. HUMBERT, R. AKÇAALAN, M. ALBAY, A. BALLOT, A. CATHERINE, J. FASTNER, K. HÄGGQVIST, M. HORECKÁ, K. IZYDORCZYK, L. KÖKER, J. KOMÁREK, S. MALOUFI, J. MANKIEWICZ-BOCZEK, J. S. METCALF, A. QUESADA, C. QUIBLIER \& C. YÉPRÉMIAN. 2017. Basic Guide to Detection and Monitoring of Potentially Toxic Cyanobacteria. In: MERILUOTO, J., SPOOF, L. \& G.A. CODD (Eds.) Handbook of Cyanobacterial Monitoring and Cyanotoxin Analysis, West Sussex, UK: John Wiley \& Sons, Ltd.

SCHLOSS, P.D., S. L. WESTCOTT, T. RYABIN, J. R. HALL, M. HARTMANN, E. B. HOLLISTER, R. A. LESNIEWSKI, B. B. RAOAKLEY, D. H. PARKS, C. J. ROBINSON, J. W. SAHL, B. STRES, G. G. THALLINGER, D .J. VAN HORN \& C. F. WEBER. 2009. Introducing mothur: Open-source, platform-independent, community-supported software for describing and comparing microbial communities. Applied and Environmental Microbiology, 75: 7537-7541. DOI: 10.1128/ AEM.01541-09

SOUSA, R, S. DIAS \& C. ANTUNES. 2007. Subtidal macrobenthic structure in the lower Lima estuary, NW of Iberian Peninsula. Annales Zoologici Fennici, 44: 303-313

TANG, C. Q., F. LEASI, U. OBERTEGGER, A. KIENEKE, T. G. BARRACLOUGH \& D. FONTANETO. 2012. The widely used small subunit $18 \mathrm{~S}$ rDNA molecule greatly underestimates true diversity in biodiversity surveys of the meiofauna. Proceedings of the Natural Academy of Sciences USA, 109: 16208-16212. DOI: 10.1073/pnas.1209160109

TESKE, P. R., J. SANDOVAL-CASTILLO, J. M. WATERS \& L. B. BEHEREGARAY. 2014. Can novel genetic analyses help to identify low-dispersal marine invasive species? Ecology and Evolution, 4: 2848e2866. DOI: 10.1002/ece3.1129

THANGARAJA M., A. AL-AISRY \& L. AL-KHARUSI. 2007. Harmful algal blooms and their impacts in the middle and outer ROPME sea area. International Journal of Oceans and Oceanography, 2 : 85-98.

VASSELON, V., I. DOMAIZON, F. RIMET, M. KAHLERT \& A. BOUCHEZ. 2017a. Application of high-throughput sequencing (HTS) metabarcoding to diatom biomonitoring: Do DNA extraction methods matter? Freshwater Science, 36: 162-177. DOI: 10.1086/690649

VASSELON, V., F. RIMET, K. TAPOLCZAI \& A. BOUCHEZ. 2017b. Assessing ecological status with diatoms DNA metabarcoding: Scaling-up on a WFD monitoring network (Mayotte island, France). Ecological Indicators, 82: 1-12. DOI: 10.1016/j.ecolind.2017. 06.024

VASSELON, V., A. BOUCHEZ, F. RIMET, S. JACQUET, R. TROBAJO, M. CORNIQUEL, K. TAPOLCZAI \& I. DOMAIZON. 2018. Avoiding quantification bias in metabarcoding: application of a cell biovolume correction factor in diatom molecular biomonitoring. Methods in Ecology and Evolution, 9: 1060-1069. DOI: 10.1111/2041-210X.12960

WILCOX, B. A. 1984. In situ conservation of genetic resources: determinants of minimum area requirements. In National Parks, Conservation and Development, Proceedings of the World Congress on National Parks. J.A. McNeely and K.R. Miller, Smithsonian Institution Press, pp. 18-30.

ZAIKO, A., A. SAMUILOVIENE, A. ARDURA \& E. GARCIA-VAZQUEZ. 2015. Metabarcoding approach for nonindigenous species surveillance in marine coastal waters. Marine Pollution Bulletin, 100: 53e59. DOI: 10.1016/ j.marpolbul.2015.09.030 